\title{
Investigations in associated protozoa-bacterial infections of cyprinids from a fish farm situated on the Jijia river in N-E of Romania
}

\author{
[Investigações sobre infecções protozoárias-bacterianas associadas a ciprinídeos da \\ exploração piscícola no rio Jijia, situado no NE da Romênia] \\ M. Lazăr ${ }^{1}$, L. Miron ${ }^{1}$, I. Gostin ${ }^{2}$, C. Rîmbu ${ }^{1}$, R. Lazăr ${ }^{3}$, E. Guguianu ${ }^{1}$ \\ ${ }^{1}$ UASVM of Iasi, Faculty of Veterinary Medicine, 8 Mihail Sadoveanu Alley, Iasi, Romania \\ ${ }^{2}$ Al. I. Cuza University of Iasi, Faculty of Biology, 11 Carol I Boulevard, Iasi, Romania \\ ${ }^{3}$ UASVM of Iasi, Faculty of Animal Science Iasi, 3 Mihail Sadoveanu Alley, Iasi, Romania
}

\begin{abstract}
In autumn 2011 in cyprinid farms located in Iasi on the Jijia river, several infections with bacterial strains and macroscopical external cysts on the skin were diagnosed, which developed as a result of the stress induced by biotic and abiotic factors. On the examination of the cyst contents the presence of numerous spores was observed, mostly of the Dermocystidium $s p$ genus. The samples were taken from the common carp (Cyprinus carpio) and crucian carp (Carassius auratus gibelio) species from the fish farm as well as from the Jijia River. 35 fish were examined, all of them showing cysts, fragmentation of their dorsal fin and congestion of the gills. Histological examination of the skin showed a field of multiple dermal cysts with round light eosinophilic formations $(14-16 \mu \mathrm{m})$ containing a central refractable body similar to that reported for Dermocystidium sp. Gills samples were taken from the affected areas for the SEM examination with the purpose of evaluating not only aspects of normal morphology, but also aspects of some modifications of the affected areas as well as the presence of the etiologically incriminated bacteria Pseudomonas fluorescens. The isolates were identified through phenotypic methods. All the strains that showed mobility and oxidase-positivity were tested using API 20 NE strip. Consequently, they were taxonomically grouped into the species Pseudomonas fluorescens. The scanning electron microscope (SEM) was used for the first time in the characterization of the bacterial lesions produced by Pseudomonas strains on Cyprinus carpio and Carassius auratus gibelio gills. The diagnosis of septicemia with conditional pathogen species of Pseudomonas fluorescens was correlated with the results of the physico-chemical investigations of water and the data concerning the breeding conditions of the investigated livestock.
\end{abstract}

Keywords: cyprinids, Pseudomonas, Dermocystidium, SEM (Scanning Electron Microscopy), histopathology

\section{RESUMO}

No outono de 2011, em fazendas de ciprinídeos localizadas em Iasi, no rio Jijia, diversas infecções bacterianas e cistos externos macroscópicos na pele se desenvolveram como resultado do estresse induzido por fatores bióticos e abióticos. No exame do conteúdo dos cistos, a presença de diversos esporos foi observada, a maioria do gênero Dermocystidium sp. As amostras foram colhidas das seguintes espécies: carpa comum (Cyprinus carpio) e carpa cruciana (Carassius auratus gibelio) de fazenda piscícola, além do rio Jijia. Assim sendo, 35 peixes foram examinados, todos demonstrando cistos, fragmentação da barbatana dorsal e congestão das guelras. O exame histológico da pele mostrou um campo de múltiplos cistos dérmicos com formações circulares claras eosinofilicas (14-16um) contendo corpo central refratado similar ao relatado para Dermocystidium sp. Amostras de guelras foram retiradas das áreas afetadas para exame MEV, com o propósito de se avaliar não apenas os aspectos da morfologia normal, mas também os aspectos de algumas modificações das áreas afetadas,

Recebido em 12 de julho de 2012

Aceito para publicação em 21 de outubro de 2013

E-mail: lazar_mircea@yahoo.com 
além da presença da bactéria etiologicamente incriminada: Pseudomonas fluorescens. Os isolados foram identificados por meio de métodos fenotípicos. Todas as amostras que mostraram mobilidade e positividade-oxidase foram testadas usando-se fita API $20 \mathrm{NE}$. Consequentemente, estas foram taxonomicamente agrupadas na espécie Pseudomonas fluorescens. O microscópio eletrônico de varredura (MEV) foi usado pela primeira vez na caracterização de lesões bacterianas produzidas por Pseudomonas nas guelras de Cyprinus carpio e Carassius auratus gibelio. O diagnóstico de septicemia com espécies condicionais de patogênico de Pseudomonas fluorescens foi correlacionado com os resultados das investigações físico-químicas da água e de dados sobre as condições de reprodução dos animais investigados.

Palavras-chave: ciprinídeos, Pseudomonas, Dermocystidium, MEV (microscópio eletrônico de varredura), histopatologia

\section{INTRODUCTION}

Dermocystidium $s p$. - the studied group of organisms - is causing white, macroscopic nodules on the skin or gills of many fish species (Hatai, 1989). Dermocystidium is probably related to the protozoa or to the fungi, but its classification is unclear (Dyková and Lom, 1992; Hoffman, 1999).

Members of the Dermocystidium genus infect a variety of fish hosts. Several species of Dermocystidium infecting skin, fins and gills have been reported. Apart from a few pathogenic species, most infections are considered to be relatively innocuous, although many are still poorly registered in scientific literature (Feist, 2004).

The systemic infection with parasitic organisms such as Dermocystidium sp. caused visceral granuloma and mortality in farmed gold fish Carassius auratus in commercial fish-farms in Israel (Landsberg, 1992).

The fish bacterial infections may develop into bacteremia, which leads to the occurrence of bacterial organisms in the bloodstream without clinical signs. In other cases septicemia may occur, which indicates the presence of bacteria and toxins in the circulatory system, accelerating the disease as well as the clinical signs. Gramnegative bacteria are responsible for the production of either exotoxins or endotoxins, which are composed of proteolytic enzymes that destroy host cells and may produce necrosis or cause blood vessel porosity or hemorrhaging (Inglis et al., 2001; Kirjusina et al., 2007).

The Pseudomonas species are uniformly distributed and can be isolated from a large variety of environmental and water samples. The aeromonads and pseudomonads are frequently considered the most widespread secondary invaders of the damaged tissues isolated from diseased carp and responsible for clinical disease and mortality.

As a general rule, the conditionally pathogenic bacteria inherent to the natural aquatic environment and fauna microbiota are manifesting their pathogeny especially in the breach of the natural anti-infectious barriers (the skin and the mucosa), as well as in immunosuppressant conditions generated by various stress factors. The stress factors triggering these diseases include low water temperature, $\mathrm{pH}(<6$ and $>9)$, nitrites $(>0.03 \mathrm{mg} / \mathrm{l}$ $\mathrm{NO}_{2}$ ), or ammonia $\left(>0.2 \mathrm{mg} / \mathrm{l} \mathrm{NH}_{3}\right.$ ) (Austin, 2007; Hoole, 2001).

The surface of the lamellar epithelium of the gills is rough and the epidermal surface has microvillus. These prolongations help cuticular mucus to reduce infections, abrasions, and they also play an important role in gas, water and ion exchange processes. Each lamella is considered to be a thin cell coating with two surfaces joined by supporting cells (Kenneth, 1996; EirasStofella et al. 1997; Ferguson 2006).

In the following report we describe the microscopic and ultramicroscopic features of the infection induced by Dermocystidium sp. and Pseudomonas fluorescens in farmed cyprinids from Iasi.

\section{MATERIALS AND METHODS}

The investigations were carried out on 35 cyprinids: 7 common carps (Cyprinus carpio) and 25 crucian carps (Carassius auratus gibelio) 
patients from Piscicola - Larga Jijia fish farm and 3 crucian carps (Carassius auratus gibelio) free from the watercourse of the Jijia River, ranging in size from 20 to $60 \mathrm{~cm}$. All 35 fish presented visible cysts breaking through the skin. All the investigations included bacteriological, histological and scanning electron microscopy (SEM) analyses.

The skin samples were fixed in $10 \%$ formalin, then were embedded in paraffin and cut at $5 \mu \mathrm{m}$ thickness and stained with Haematoxilin and Eosin for general histomorphology. Additional sections were stained using Grocott and Periodicacid Schiff (PAS) in an attempt to identify the possible presence of the hyphal elements in the tissues.

Photographs and digital images were taken using a LEICA ICC50 HD photomicroscope.

The bacteriological exam consisted of microscopic investigation of skin and gill lesions on Gram stained smears and of inoculated samples prelevated from kidney and blood by heart puncture, following the necropsy in strict aseptic conditions.

The used media were blood agares, which, after being inoculated, were incubated at $25^{\circ} \mathrm{C}$, for 24 48 hours.

The identification of isolates was based on culture aspects, on the ability to grow at refrigerated temperature $\left(4^{0} \mathrm{C}\right)$, on the bacterial cell morphology in Gram stained smears as well as metabolic properties. The metabolic properties have been tested using classic tests and API 20 NE strip (bioMérieux), following the instructions recommended by the manufacturers.

The oxidase test is a preliminary differentiation exam between Enterobacteriaceae (oxidase negative) and other Gram negative bacteria.

The isolates antibiotic susceptibility was carried out using the standardized CLSI diffusimetric method on MÜLLER Hinton agar.

Subsequently, several physicochemical exams of water from tanks with sick fish were conducted: temperature, $\mathrm{pH}$, nitrite concentration, nitrates, ammonium, chloride and dissolved oxygen.
Scanning electron microscopy (SEM) investigations: the investigated material consists of small gill pieces. The material was fixed in glutaraldehyde $(2 \%)$ for 2 hours, osmium tetraoxide $(1 \%)$ for 4 hours and washed with phosphate buffer. After dehydration in a graded ethanol series $(40 \%, 70 \%, 80 \%, 90 \%$ and $100 \%)$ and acetone, the material was critical-point dried with $\mathrm{CO}_{2}$ (using an EMS 850 Critical Point Dryer), sputter-coated with a thin layer of gold (30 nm) (using an EMS 550X Sputter Coater) and, finally, examined by scanning electron microscopy (Tescan Vega II SBH) at an acceleration voltage of $27.88 \mathrm{~V}$.

\section{RESULTS AND DISCUSSION}

During September and November 2011 several fish cases showed well-circumscribed cysts and phagocytic reaction (Figure 1, 2, 3). Affected species included the common carp and the crucian carp, one or two summers old, from the cyprinid fish farms located along the Jijia River.

Histologically the spores are spherical, with an average diameter of $8 \mu \mathrm{m}$ with marginated sporal cytoplasm and nucleus, which was displaced by the characteristic central refractile body or "vacuoplast". The cytoplasm and nucleus are marginated, but no germination of the spores producing hyphal outgrowths was observed (Figure 4, 5). In some spores the cytoplasm was positively stained by the PAS method. The vacuole gave a weakly positive and variable reaction with PAS but was intensely acidophilic when stained using the Grocott technique (Figure $6,7)$.

In general the cysts were located in the subepithelial dermal tissues. The wall of the cyst consisted of a $5-7 \mu \mathrm{m}$ layer of densely staining acidophilic material (Figure 8, 9). The intensity of the color appeared to be dependent on the maturity of the cyst wall showing the strongest affinity for acidic dyes (chromotrope in Gomori stain). No ruptured walls were observed, but invariably in these cases there was a host inflammatory response involving both the epidermis and the dermal tissues. The presence of macrophages or other phagocytic cells was prominent in these areas, although no clear examples of Dermocystidium sp. phagocytosis were observed (Figure 10,11). 


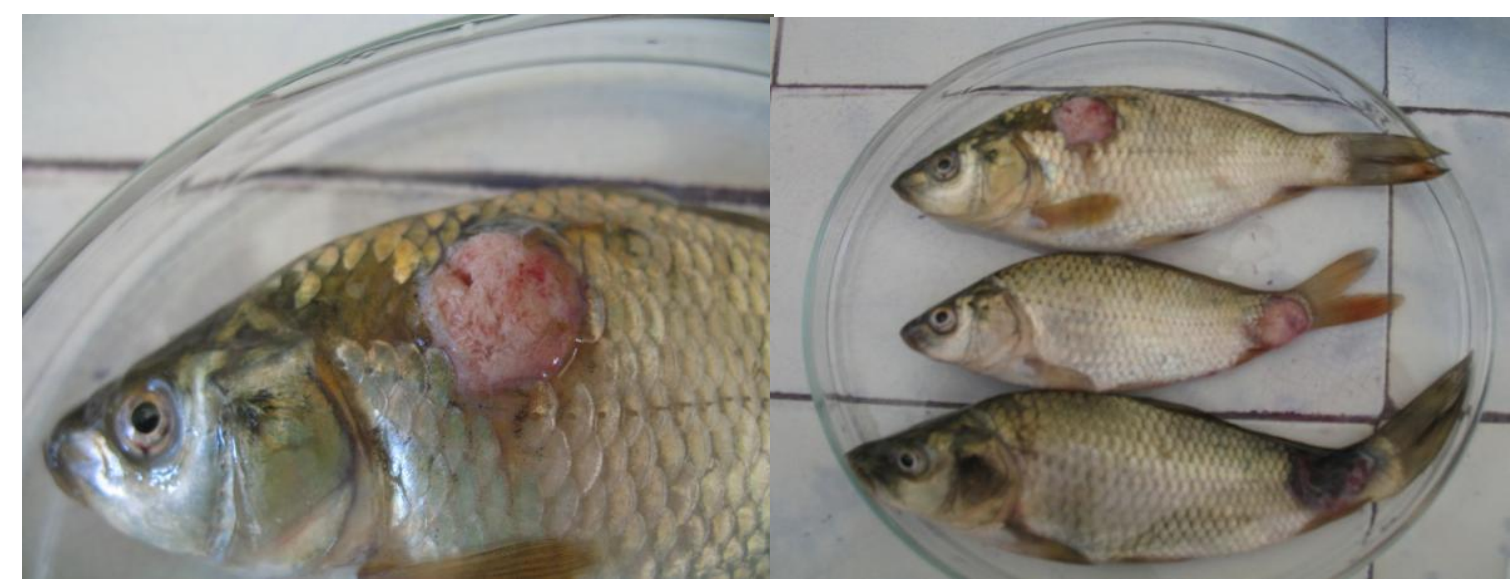

Figure 1. Crucian carp. White cutaneous cyst Figure 2. Crucian carp. Cyst in ventral and surrounded by a whitish ring. caudal areas.

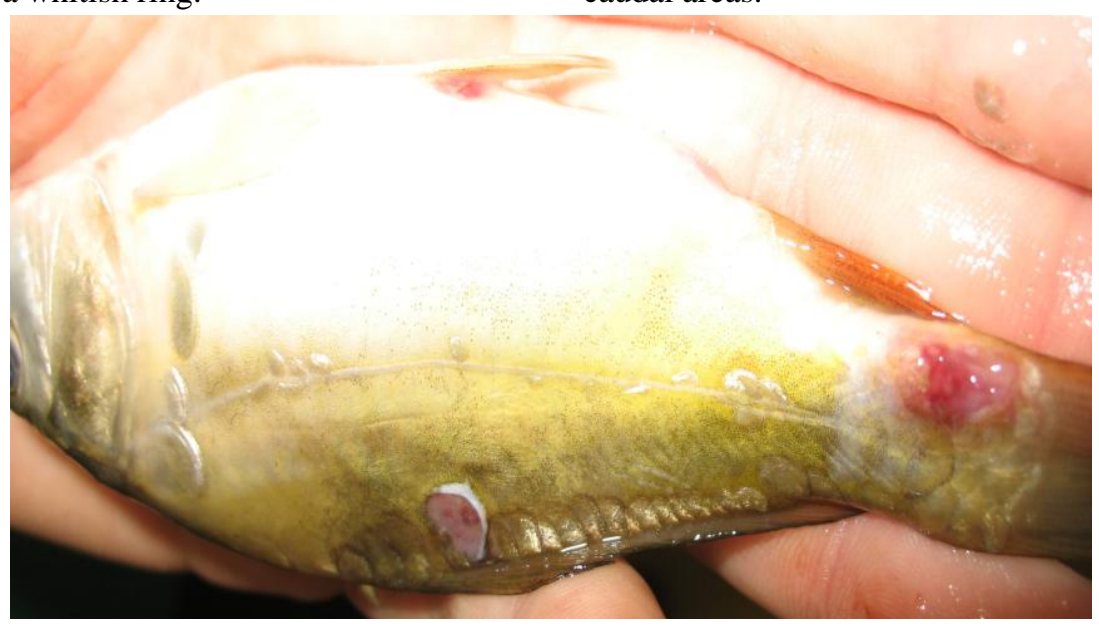

Figure 3. Common carp - caudal cyst.

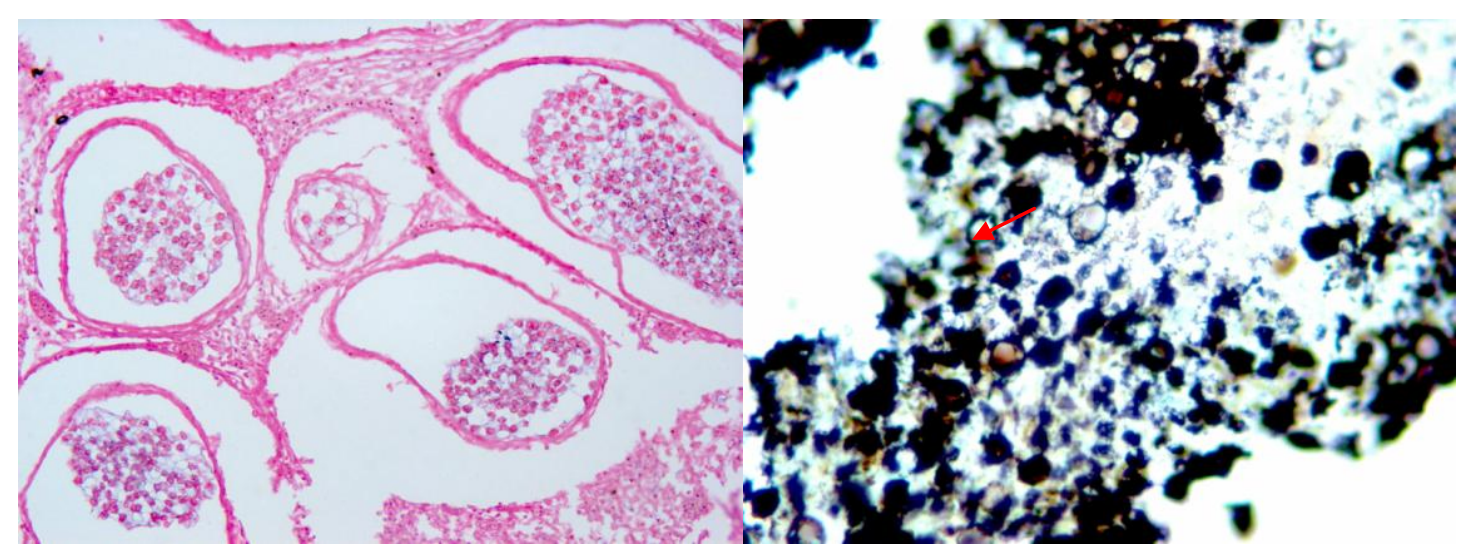

Figure 4. Cysts with Dermocystidium sp., intact wall, HE, 20x
Figure 5. Dermocystidium sp. spores characterized by a large central vacuole or refractile body (arrow), Grocott, 63x 


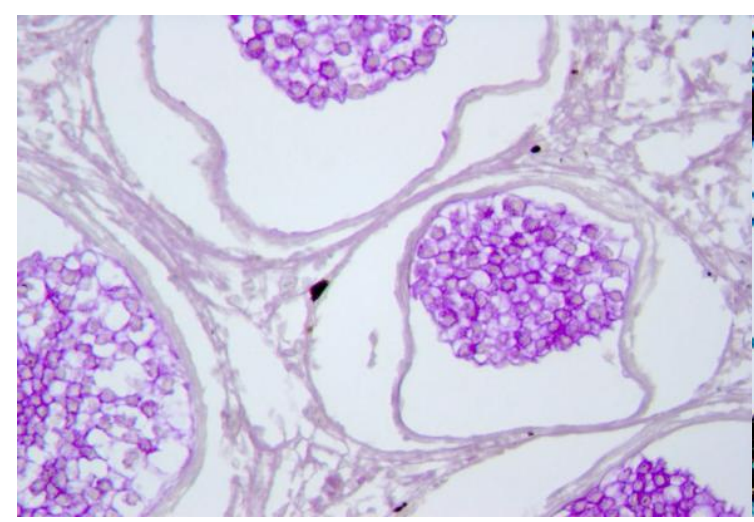

Figure 6. Cytoplasm is weakly positive in PAS, 40x.

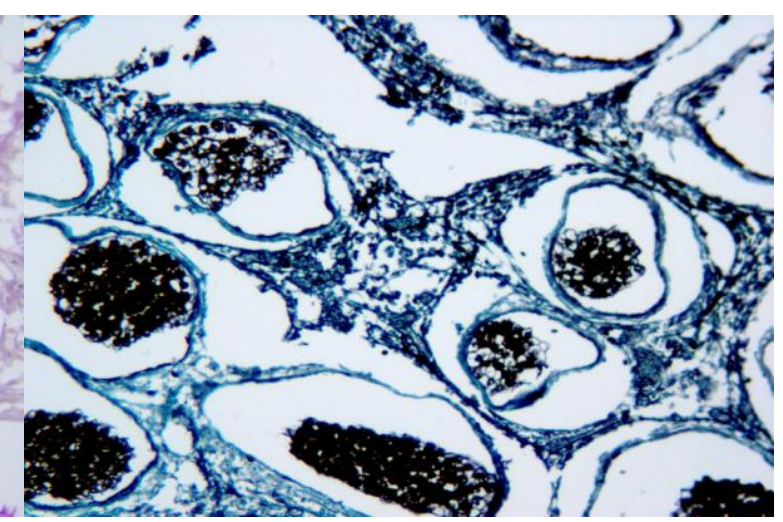

Figure 7. Section through Dermocystidium sp. Darkly stained spores are visible within the cyst, Grocott, 40x

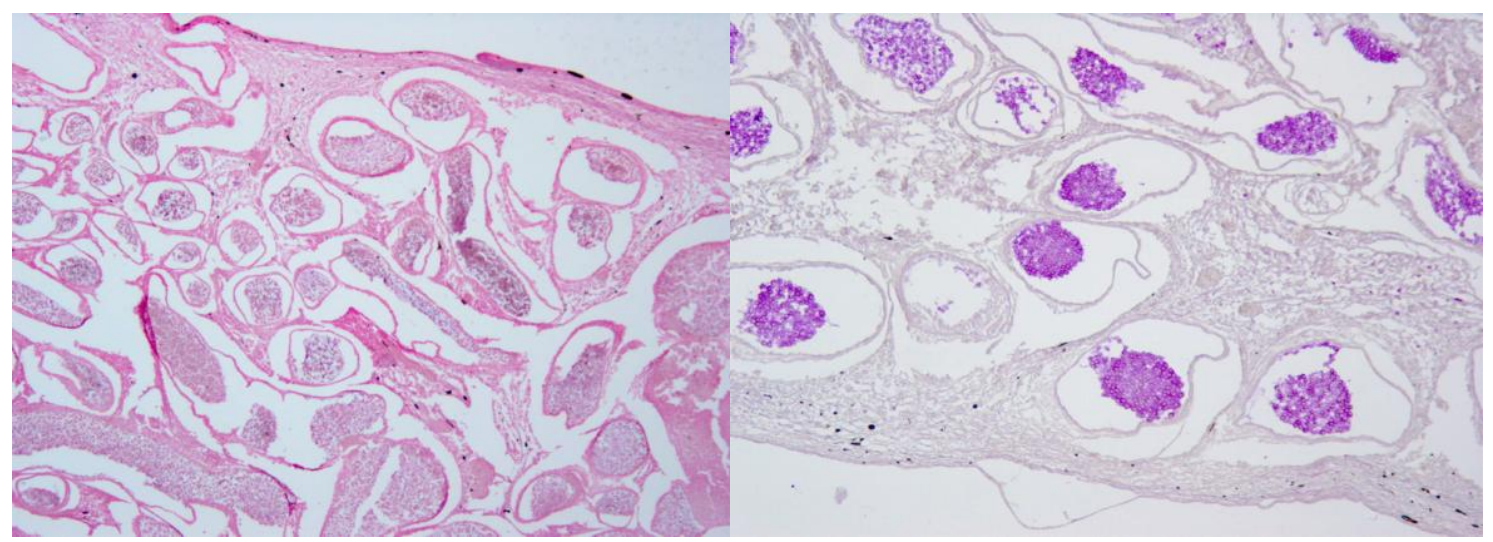

Figure 8. Location of the cysts in the subepithelial Figure 9. Location of the cysts in the subepithelial dermal tissue, HE, 10x. dermal tissue, PAS, 10x.

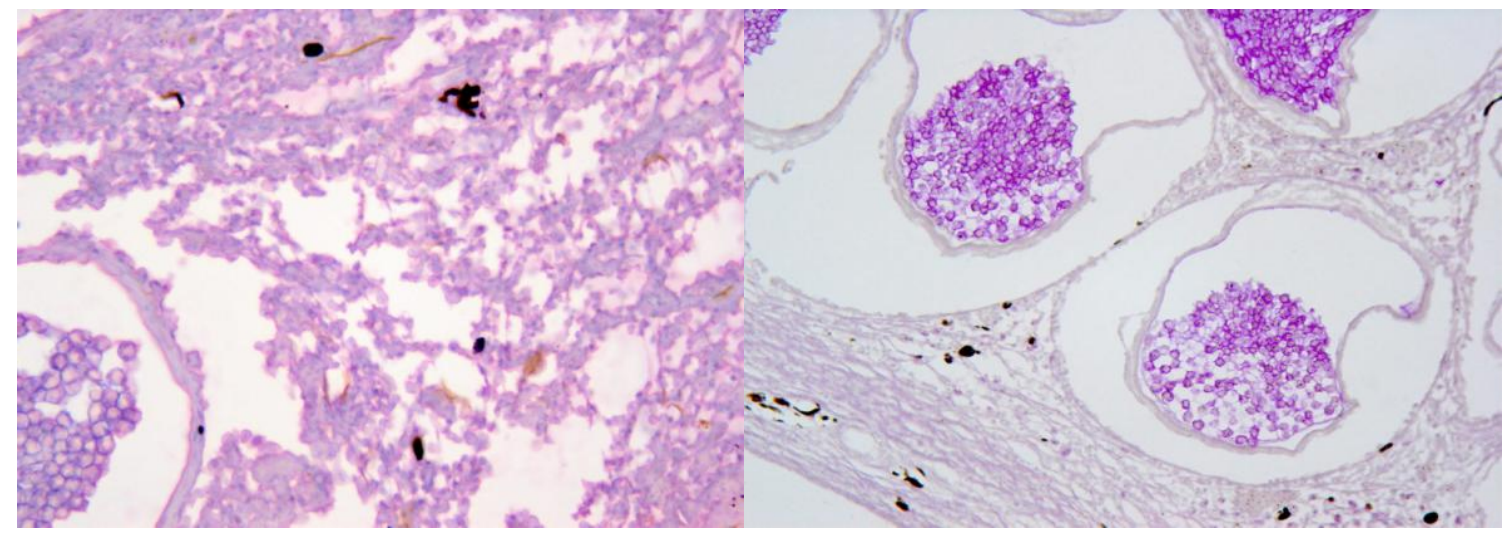

Figure 10. Section with cyst walls and mild infiltration with host lymphocytes and melanomacrophages in tissue, HE, 40x.
Figure 11. Mild infiltration with host lymphocytes and melanomacrophages in tissue, PAS, 20x. 
Histologically the lesions of the branchial lamelles consist of the desquamation of the respiratory epithelium, punctiform hemorrhages, abundant mucus, accentuated branchial necrosis leading to complete lyses of the branchial lamella, and the degeneration of the basal cartilage due to depolymerization of the acid mucopoliosides (Figure 12, 13).

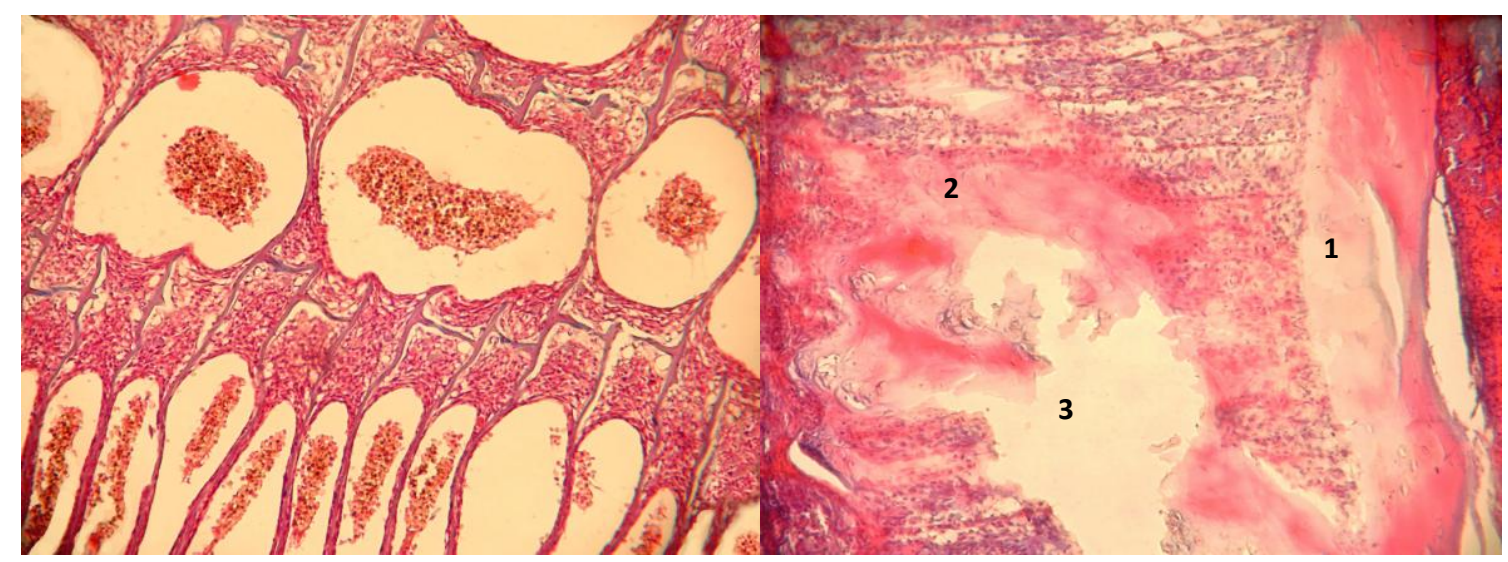

Figure 12. Gill lamella. Basal congestion (1). Figure 13. Basal cartilage degeneration (1). Slide Interlamellar haemoragies (2). HEA, 10x

The bacterioscopic examination of the cutaneous and the gill lesions highlighted the presence of the gram-negative rods bacteria. Pure cultures of Pseudomonas fluorescens were recovered from kidneys and fish blood.

The Pseudomonas fluorescens strains were identified by positivity of the following characteristics, according to Austin, (2007): fluorescent colonies in UV, occurances at $4^{\circ} \mathrm{C}$, motility, gram negative rod shape, cytocrome oxidase, reduction of nitrates, gelatin liquefaction, citrate assimilation. The strains were confirmed by using the API test by referring to the identification software. The presence of bacteria in the blood and normally sterile organs established the sepsis diagnosis.

Antibiograms showed that the isolated bacteria are sensitive to imipenem $(10 \mu \mathrm{g})$, amoxycilin/

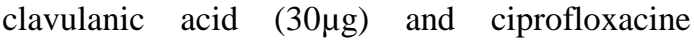
$(30 \mu \mathrm{g})$. They were resistant to ampicilin $(30 \mu \mathrm{g})$, gentamycin $(30 \mu \mathrm{g})$, chloramphenicole $(30 \mu \mathrm{g})$, oxacillin $(10 \mu \mathrm{g})$ and cloxacilline $(25 \mu \mathrm{g})$.

Electronomicroscopic examination of the gills showed long lines of fine filaments (primary lamellae) placed on each gill arch like the teeth of a comb. The surface of each main lamella is gill necrosis (2). The liza of slide gill (3). HEA, $10 \mathrm{x}$

completed by semilunar formations on its dorsal and ventral surfaces, so they fit the free space between rows of adjacent filaments. This type of arrangement filters the water. Along the lamellae one can notice the opening of the goblet cells (Figure 14, 15, 16).

The external layer of the lamellar epithelium is composed of small twisted prominences in the shape of prints. Among bacteria, light ovoid cells can be seen; the most probable explanation in any mucosal surface that is being damaged is that they are mucosal blebs - they have no remnants of microridges, they could also be the "X cells" described in literature (Figure 17, 18).

Ferguson (2006) mentions that these "X cells" are often found in large amounts since they indicate neoplasic processes. They are found at the base and along the lamellae, being placed between the epithelial and the support cells.

In some cases necrotic processes of the external epithelial layer of the lamella were noticed. In those cases the small prominences are hardly noticeable or disappear completely and colonies of Pseudomonas fluorescens may be observed (Figure 19). 


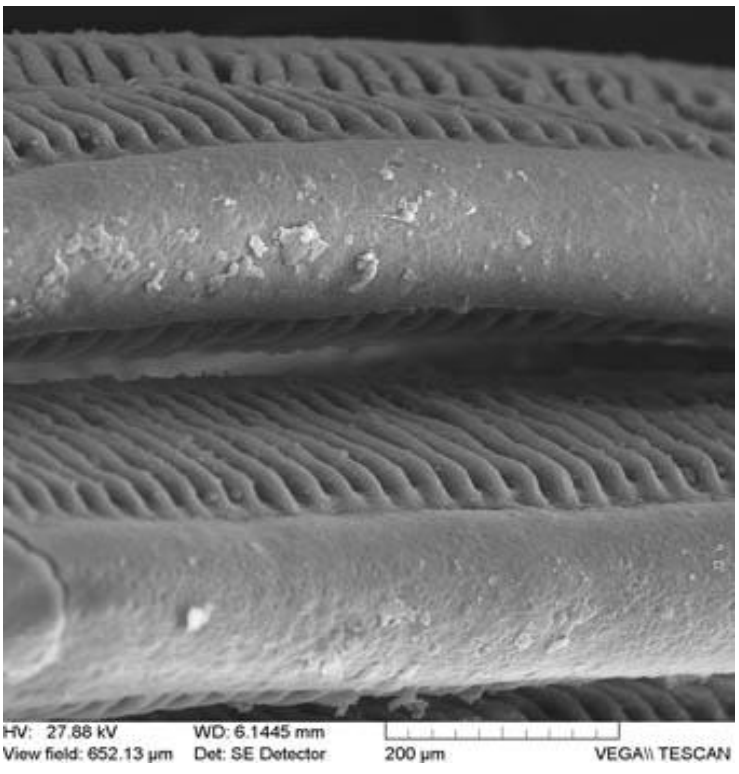

Figure 14. SEM. General view of main and secondary lamellas.

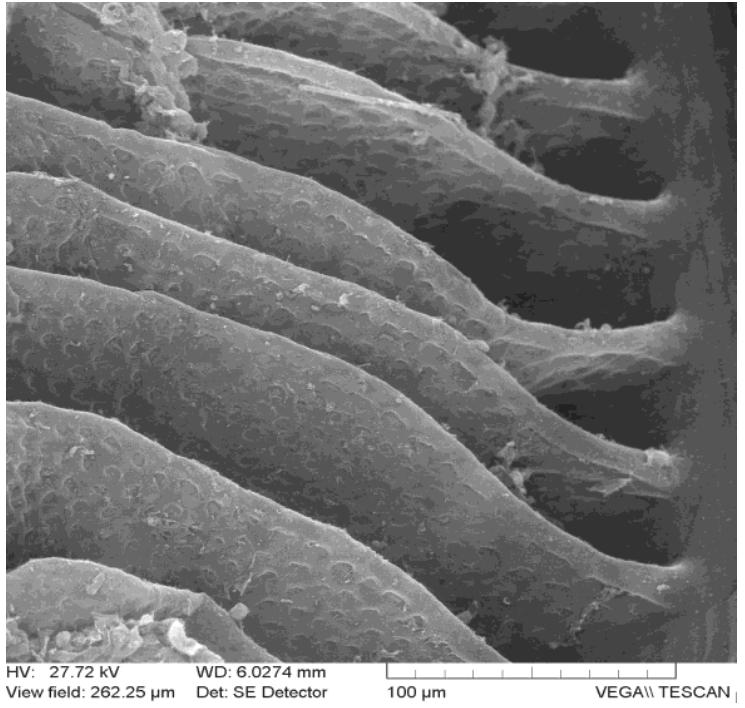

Figure 16. SEM. Gill. Secondary lamellas' joint on main lamella.

The results of the physico-chemical examinations of water lead to the conclusion that Pseusomonas fluorescens septicemia occurred as a consequence of the immunosuppression induced by the water temperature $\left(10-15^{\circ} \mathrm{C}\right)$, which is below the thermal comfort limit for cyprinids $\left(22-25^{\circ} \mathrm{C}\right)$ and due to the chemical stress caused by the high percent of nitrites $(1.25 \mathrm{mg} / \mathrm{L}$ compared to $0.03 \mathrm{mg} / \mathrm{L}-$ the

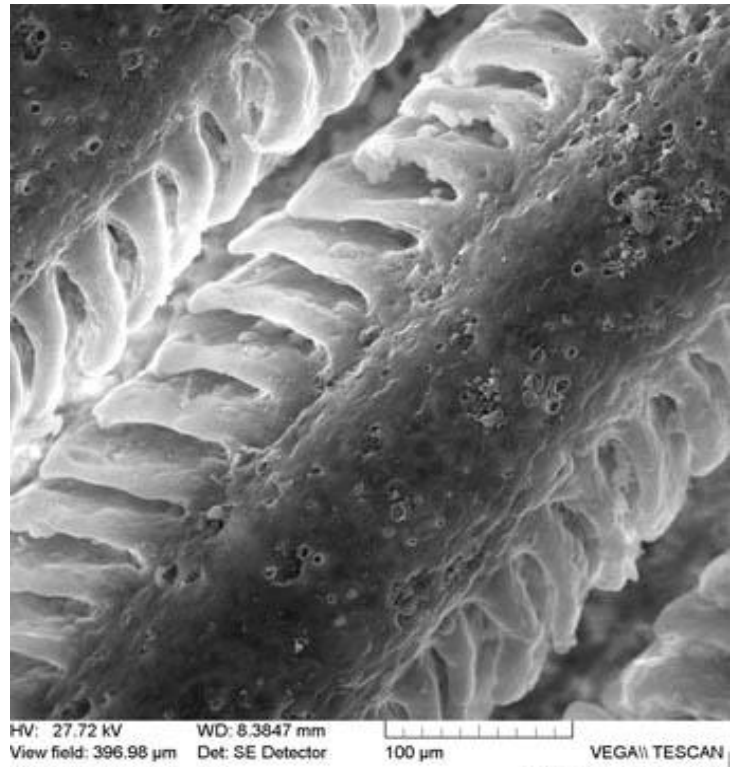

Figure 15. SEM. Main lamellas on which mucous cell pores may be noticed.

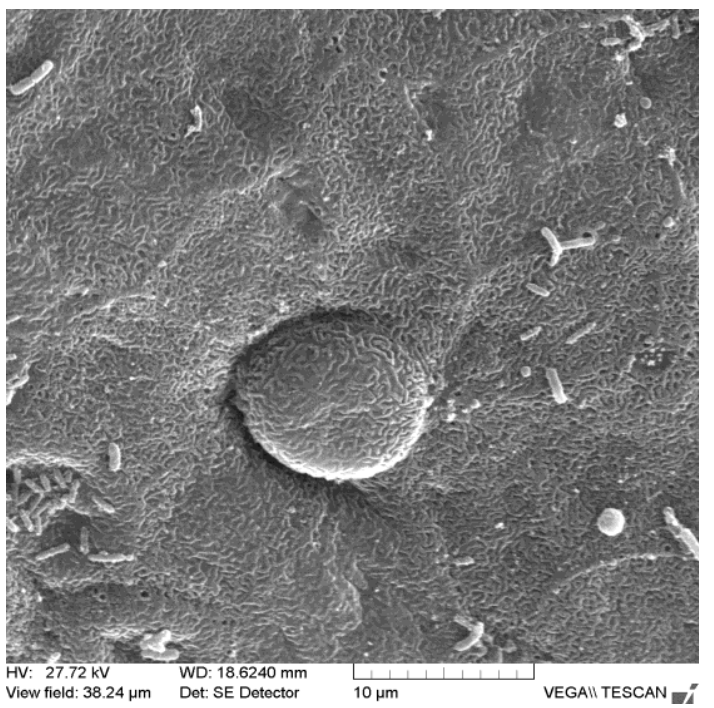

Figure 17. SEM. Gill. Exposure of external lamellar epithelium as a digital mark and mucosal blebs

maximum limit accepted) and ammonia $(0.485 \mathrm{mg} / \mathrm{L}, \quad$ compared to 0.2 - $1,00 \mathrm{mg} / \mathrm{L})$ (Table 1).

A major role in septicemia production was attributed to cutaneous lesions caused by parasites, which formed true access points for opportunistic pathogens. 


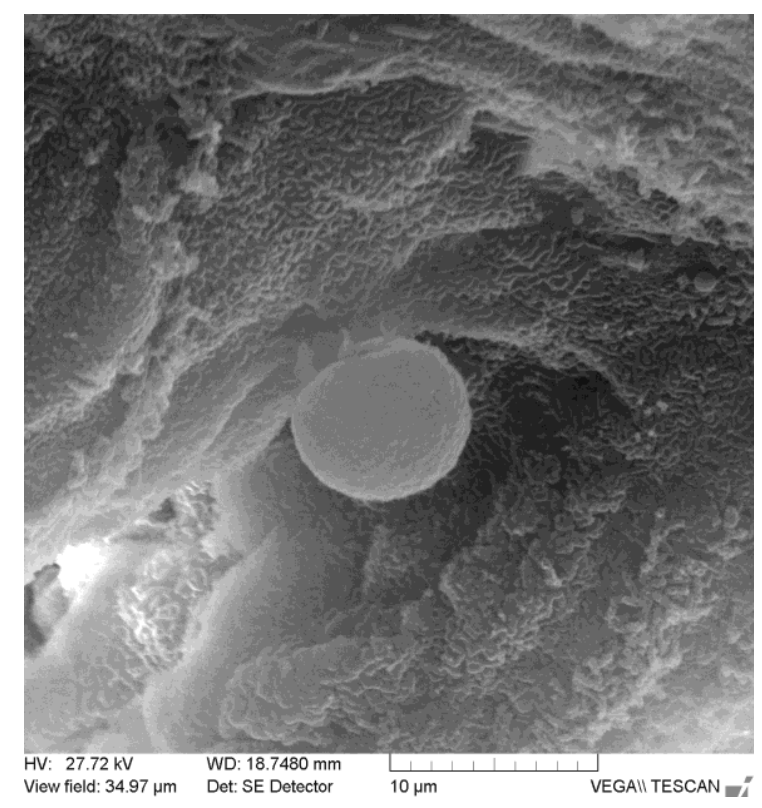

Figure 18. Gill. Mucosal blebs with ovoid appearance and light color, placed between 2 secondary lamellas.

Table 1. Chemical parameters of river water fish growth

\begin{tabular}{ll}
\hline Parameters & Recorded value \\
\hline $\mathrm{pH}$ & 7.02 \\
Nitrites $(\mathrm{mg} / \mathrm{L})$ & $1.25 \mathrm{mg} / \mathrm{L}$ \\
Nitrates $(\mathrm{mg} / \mathrm{L})$ & Absent \\
Ammonia $(\mathrm{mg} / \mathrm{L})$ & $0.485 \mathrm{mg} / \mathrm{L}$ \\
Chlorures $(\mathrm{mg} / \mathrm{L})$ & $21.5 \mathrm{mg} / \mathrm{L}$ \\
\hline
\end{tabular}

\section{CONCLUSIONS}

The Dermocystidium spores are spherical, with marginated sporal cytoplasm and a nucleus which is displaced by the characteristic central refractile body. The presence of melanomacrophages and other phagocytic cells is proeminent in the cyst area, but there are no clear examples of phagocytosis of Dermocystidium $s p$. The cytoplasm of the spores is positively stained by the PAS method and intensely acidophilic when it is stained using the Grocott technique. The Pseudomonas fluorescens septicemia in cyprinids from farms in the county of Iasi was favored by low water temperature $\left(10-15^{\circ} \mathrm{C}\right)$, by Dermocystidium $s p$. infestations and by improper water quality, considering the nitrites and ammonia content. In the areas where the gills were injured, the electronomicroscopic examinations indicated the

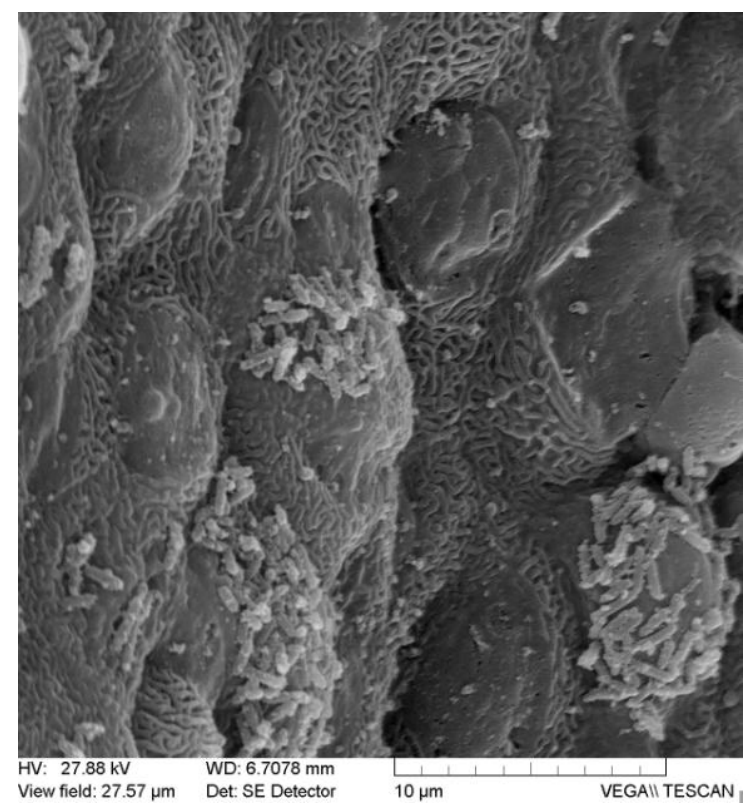

Figure 19. Gill. Necrosis zones and colonies of Pseudomonas fluorescens.

presence of the Pseudomonas fluorescens bacteria as a result of some necrotic lesions, with denudation of the lamellae due to bacteria infestations.

\section{REFERENCES}

AUSTIN, B.; AUSTIN, D. Bacterial Fish Pathogens. Diseases of Farmed and Wild Fish. 4. ed. Chichester: Praxis Publishing, p. 20-553, 2007.

DYKOVA, I.; LOM, J. New evidence of fungal nature of Dermocystidium koi Hoshina and Saraha. J. Appl. Ichthyol., v.8, p.180-185, 1992.

FEIST, S.W.; LONGSHAW, M.; HURRELL, R.H.; MANDER, B. Observations of Dermocystidium sp. infections in bullheads, Cottus gobio L., from a river in southern England. J. Fish Diss, v.27, p.225-231, 2004.

HATAI, K. Fungal pathogens/parasites of aquatic animals. In: AUSTIN, B.; AUSTIN, D.A. editors: Methods for microbiological examination of fish and shellfish. John Wiley and Sons, New York, p. 240-272, 1989.

HOFFMAN, L.; GLENN. Parasites of North American Freshwater Fishes. 2.ed. Correll University Press, SUA, p. 9-92, 1999. 
HOOLE, D.; BUCKE, D.; BURGESS, P.; WELLBY, I. Diseases of Carp and Other Cyprinid Fishes. London: Fishing News Books, p.53, 2001.

INGLIS, V.; ROBERTS, R.J.; BROMAGE, N.R. Bacterial Diseases of Fish. London: Blackwell Scientific Publications, p.1-59 e p.122 -156, 1993.

KENNETH, R.O. Scanning Electron Microscopy Of the Fish Gill. In. DATTA MUNSHI, J.S.; DUTTA, M. Fish morphology, horizon of new research: New Hampshire: Science Publishers Inc., p.31-45, 1996.

KIRJUSINA, M.; BRIEDE, I.; BONDADREANTASO, M.G. Extension Manual on Some Important Viruses, Parasites and Bacteria of Aquatic Animals in Latvia: NDC/LZRA/FAO, Riga, p.69, 2007.
EIRAS-STOFELLA, D.R.; CHARVET-ALMEIDA, P. Gills of the freshwater fish Hypostomus commersonii Val., 1840 (Loricariidae) analysed through electron microscopy techniques. Arq. Biol. Tecnol., v.40, p.785-792, 1997.

FERGUSON, H.W. Systemic Pathology of Fish: a text and atlas of normal tissues in teleosts and their responses in disease. Second Edition, Scotian Press, London, p.5-263, 2006.

LANDSBERG, J.H.; PAPERNA, I. Systemic granuloma in goldfish caused by Dermocystidium - like aetiological agent. Dis. Aquat. Org., v.13, p.75-78, 1992. 